\title{
Choroid Hemangioma
}

National Cancer Institute

\section{Source}

National Cancer Institute. Choroid Hemangioma. NCI Thesaurus. Code C4562.

A hemangioma arising from the choroid. 